\title{
Pengaruh Pelatihan Dan Kedisiplinan Terhadap Kinerja Karyawan Pada PT. Cakrawala Citramega Multifinance
}

\author{
N. Lilis Suryani, S.E., M.M. \\ Dosen Fakultas Ekonomi Universitas Pamulang \\ Email : dosen00437@unpam.ac.id
}

\begin{abstract}
ABSTRAK
Penelitian ini bertujuan untuk mengetahui apakah terdapat pengaruh yang signifikan antara pelatihan (variabel $\mathrm{X}^{1}$ ) dan disiplin (variabel $\mathrm{X}^{2}$ ) dengan kinerja karyawan (variabel Y). Hipotesis penelitian yang diuji adalah terdapat pengaruh yang signifikan antara pelatihan dan disiplin dengan kinerja karyawan Pada PT. Cakrawala Citramega Multifinance

Metode penelitian yang digunakan penulis adalah metode deskriptif kuantitatif karena data yang didapat berbentuk angka-angka dengan menggunakan kuesioner. Populasi dalam penelitian ini adalah seluruh karyawan Pada PT. Cakrawala Citramega Multifinance yang berjumlah 35 orang. Sampel dalam penelitian ini diambil dari jumlah populasi yang berjumlah 35 orang/responden. Data yang penulis dapatkan dari metode observasi, wawancara dan data kuesioner.

Berdasarkan hasil penelitian menunjukan terdapat pengaruh yang signifikan antara pelatihan dan disiplindengan kinerja karyawan dengan koefisien korelasi sebesar rxy $=0,508$, uji reliabilitas variabel $X^{1}=0,757$, uji reliabilitas variabel $X^{2}$ $=0,569$, uji reliabilitas variabel $\mathrm{Y}=0,663$, data tersebut dikatakan reliabel karena nilai $\mathrm{r}_{\text {-hitung }}$ lebih besar dari nilai $\mathrm{r}$-tabel yang sebesar 0,334. Untuk uji koefisien determinasi $\left(\mathrm{KD}=\mathrm{r}^{2} 100 \%\right)$ didapat hasil sebesar $=25,80 \%$ yang artinya variabel $\mathrm{X}^{1}$ dan variabel $\mathrm{X}^{2}$ berpengaruh dengan variabel $\mathrm{Y}$ sebesar $25,80 \%$, sedangkan $74,20 \%$ dipengaruhi oleh faktor lainnya. Dan uji Simultan di dapati f-hitung sebesar $=5,5652$, yang artinya variabel Pelatihan dan disiplin secara Simultan berpengaruh sangat signifikan terhadap kinerja karyawan.karena nilai f-hitung $(5,5652)$ lebih besar dari nilai $\mathrm{f}_{\text {-tabel }}(3,30)$. Hasil penelitian ini dapat disimpulkan bahwa terdapat pengaruh yang positif signifikan antara pelatihan dan disiplin terhadap kinerja karyawan Pada PT. Cakrawala Citramega Multifinance
\end{abstract}

\section{Kata Kunci : Pelatihan, Disiplin, Kinerja Karyawan}




\section{PENDAHULUAN}

\section{Latar Belakang}

Dalam sebuah organisasi, menejemen yang baik adalah ketika seluruh sistem keorganisasian berjalan sesuai peranan dan fungsinya masing-masing ,baik dari segi perencanaan nya maupun aktualisasi dari apa yang telah di rencanakan sehingga dapat mencapai tujuan dari perusahaan atau organisasi tersebut. Melihat hal ini sumberdaya manusia (SDM) yang di anggap sebagai hal penting dalam sebuah organisasi atau perusahaan haruslah miliki kapasitas dan kemampuan yang mempuni untuk mengaplikasikan segala hal yang telah di tetapkan oleh organisasi atau perusahaan guna mencapai tujuan yang di inginkan secara maksimal, efektif dan efisien.

Hasil dari sebuah kinerja sangatlah penting karena dapat kemampuan nya agar dapat bertahan di tengah kemajuan zaman dan ketatnya persaingan.

Untuk mendapatkan sumber daya manusia yang cakap dan profesional organisasi perusahaan juga harus memiliki system yang baik, terutama sistem rekrutmen yang di mulai dari proses seleksi, penerimaan, berbagai tes - tes, penempatan, sampai ke tahap pengembangan. Kemudian upaya lain yang di lakukan untuk meningkatkan kinerja dan kemampuan karyawan tersebut adalah dengan melakukan pelatihan

Menurut Wexley dan Yukl yang di kutip oleh Anwar Prabu Mangku Negara (2013:43) mengatakan bahwa pelatihan merupakan istilah yang berhubungan menentukan sejauh mana keberhasilan sebuah perencanaan kerja dapat berjalan. Aturan-aturan yang di susun dalam struktur keorganisasian perusahaan juga merupakan bagian dari cara sebuah instansi untuk memaksimalkan kinerja karyawan dan membentuk komitmen kerja guna mencapai tujuan perusahaan.

Kemampuan yang di miliki oleh sumber daya manusia (SDM) menjadi sangat penting di perhatikan oleh organisasi perusahaan di tengah persaingan teknologi yang semakin maju dari zaman ke zaman. Jika perusahaan tidak mengantisipasi hal tersebut, maka itu akan menghambat sebuah

perencanaan menejemen.Untuk itu organisasi atau perusahaan di tuntut untuk memiliki Sumber daya Manusia yang cakap dan mampu untuk bisa mengembangkan

dengan usaha-usaha berencana yang di selenggarakan untuk mencapai penguasaan skill, pengetahuan dan sikap-sikap pegawai atau anggota organisasi.

Selain kemampuan para karyawan yang harus di tingkatkan, pola sikap atau disiplin juga penting di miliki oleh seluruh karyawan, karena sikap di siplin tersebut juga dapat menunjang peningkatan kinerja yang akan di hasilkan oleh seorng karyawan.

Biasanya dalam sebuah perusahaan terdapat budaya-budaya yang telah ada dalam lingkup kerja karyawan, dalam hal ini, budaya atau kebiasaaan yang hadir terkait dengan disiplin adalah bagaimana para karyawan dapat melakukan disiplin yang baik dalam bekerja sehingga 
mereka dapat memaksimalkan hasil dari kinerja mereka dengan baik pula. Contoh nya dengan datang tepat waktu, mengerjakan tugas sesuai dengan waktu yang ditetapkan, istirahat pada waktunya,dan pulang juga pada waktu yang di tentukan. Inilah yang menjadi tugas yang penting untuk sebuah perusahaan untuk membangun kondisi disiplin kerja yang baik, sehingga seluruh karyawan dapat memiliki kesadaran untuk melakukan disiplin dalam bekerja.

Singodimedjo (2002), mengatakan bahwa disiplin adalah sikap disiplin dan kerelaan seseorang untuk mematuhi dan menaati normanorma dan peraturan yang berlaku di lingkungan nya. Disiplin yang baik akan mempercepat tujuan perusahaan sedangkan disiplin yang merosot akan menjadi penghalang dan memperlambat pencapaian tujuan perusahaan.

Melihat hal ini maka penulis melihat bagaimana kesadaran pegawai yang ada Pada PT. Cakrawala Citramega Multifinance untuk melakukan disiplin dalam pekerjaan merupakan hal yang sulit di lakukan oleh individu karyawan, selain minimnya kesadaran untuk melakukan disiplin, keadaan dari lingkungan sekitar yang kurang mendukung juga bisa menjadi salah satu aspek yang mempengaruhi tingkat kesadaran untuk disiplin tersebut.

Dari sudut pandang ini dapat dilihat bagaimana hasil kinerja para karyawan Pada PT. Cakrawala Citramega Multifinance yang memiliki masalah dengan disiplin, semakin rendah kesadaran para karyawan terhadap disiplin maka kinerja mereka bisa di pastikan kurang baik bahkan bisa di katakan buruk, namun sebaliknya semakin tinggi tingkat kesadaran para karyawan terhadap disiplin maka semakin baik pula kinerja dari karyawan tersebut. Kinerja adalah hasil kerja secara kualitas dan kuantitas yang di capai oleh seorang pegawai dalam melaksanakan tugasnya sesuai dengan tanggung jawab yang di berikan kepadanya. mangkunegara (2013:67).

\section{Rumusan Masalah}

Berdasarkan latar belakang, identifikasi masalah, dan pembatasan masalah di atas maka dapat di rumuskan suatu permasalahan sebagai berikut:

1. Bagaimana pengaruh pelatihan terhadap kinerja karyawan Pada PT. Cakrawala Citramega Multifinance?

2. Bagaimana pengaruh disiplin terhadap kinerja karyawan Pada PT. Cakrawala Citramega Multifinance?

3. Bagaimana pengaruh pelatihan dan disiplin terhadap kinerja karyawan Pada PT. Cakrawala Citramega Multifinance?

\section{Kerangka Pemikiran}

Berdasarkan pemaparan di atas dapat di gambarkan kerangka pemikiran penelitian di bawah ini 
Pelatihan (variable X1) Indikator :

1. Materi yang di berikan

2. Metode yang di gunakan

3. Sarana pelatihan

4. Instruktur pelatihan

(PrabuMangkunegara 2013:44)

Disiplin (Variabel X2) Indikator :

1. Tujuan dan Kemampuan

2. Teladan Pimpinan

3. Balas Jasa

4. Keadilan

5. Waskat

6. Sanksi Hukuman

7. Ketegasan

8. Hubungan Kemanusiaan

( Hasibuan 2014 : 194 )
Gambar 1.1

Kerangka berfikir

\section{Hipotesa Penelitian}

Berdasarkan

kerangka

pemikiran diatas, maka dapat diajukan suatu hipotesa penelitian, yaitu:

1. H1 : Terdapat pengaruh Pelatihan terhadap kinerja Pada PT. Cakrawala Citramega Multifinance

2. H2 : Terdapat pengaruh Kedisiplinan terhadap Kinerja Pada PT. Cakrawala Citramega Multifinance

3. H3 : Terdapat pengaruh Pelatihan dan Kedisiplinan Terhadap Kinerja Pada PT. Cakrawala Citramega Multifinance

\section{LANDASAN TEORI \\ Pelatihan}

Pelatihan atau training, memiliki makna sebagai kegiatan untuk mentransfer pengetahuan dan keterampilan kepada seseorang dalam upaya meningkatkan kapasitas dirinya di tempat kerja atau tempatnya beraktivitas. Pada perkembangan berikutnya, terjadi pergeseran parasigma yang mengemukakan bahwa meningkatkan kapasitas seseorang lebih baik di gunakan istilah belajar atau learning, karena pelatihan hanya berbicara seputar organisasi sedangkan belajar bebicara tentang manusia.

Dalam organisasi pelatihan lebih banyak di lakukan untuk tingkat karyawan (menejemen) supervisior kebawah,karena setiap pelatihan di maksudkan untuk dapat memningkatkan kemampuan para karyawan dlam meningkat kan kinerja mereka. Menurut mondy (2011 :210) pelatihan merupakan aktivitas-aktivitas yang di rancang untuk memberikan pembelajaran, pengalaman, dan keteranmpilan yang di buthkan selama ini. Untuk meningkatkan penghasilan perusahaan tententu.

\section{Kedisiplinan}


Kedisiplinan merupakan fungsi MSDM yang terpenting dan menjadi tolak ukur untuk mengukur/mengetahui apakah fungsi-fungsi MSDM lainnya secara keseluruhan telah di laksanakandengan baik atau tidak. Kedisiplinan karyawan yang baik, mencerminkan bahwa fungsi-fungsi MSDM lainya telah di laksanakan sesuai dengan rencana. Sebaliknya jika kedisiplinan karyawan kurang baik, berarti penerapan fungsi-fungsi MSDM pada perusahaan kurang baik.

Anwar Prabu Mangkunegara (2013:129) mengutip pendapat Keith Davis (1985-366) mengemukakan bahwa "discipline is management acton to enforce organization standards". Berdasarkan pendapat Keith Davis, disiplin dapat di artikan sebagai pelaksana manajemen untuk mmemperteguh pedoman-pedoman organisasi.

Jadi dapat di katakan "Kedisiplinan" menjadi kunci terwujudnya tujuan perusahaan, Karyawan, dan Masyarakat. Dengan disiplin yang baik berarti karyawan sadar dan bersedia mengerjakan semua tugasnya dengan baik.

\section{Kinerja}

Kinerja adalah hasil kerja yang dapat dicapai oleh seseorang atau sekelompok orang dalam suatu organisasi, sesuai dengan wewenang dan tanggungjawab masing-masing, dalam rangka upaya mencapai tujuan organisasi bersangkutan secara legal, tidak melanggar hukum dan sesuai dengan moral dan etika, Prawirosentono dalam Sinambela (2012:5). Rumusan di atas menjelaskan bahwa kinerja adalah tingkat keberhasilan seseorang atas lembaga dalam melaksanakan pekerjaannya. Dari definisi di atas, terdapat setidaknya empat elemen yaitu: (1) hasil kerja yang dicapai secara individual atau secara instansi, yang berarti bahwa kinerja tersebut adalah "hasil akhir" yang diperoleh secara sendiri - sendiri atau berkelompok (2) dalam melaksanakan tugas, orang atau lembaga diberikan wewenang

Kinerja Pegawai; Teori, Pengukuran dan Implikasi dan tanggung jawab, yang berarti orang atau lembaga diberikan hak dan kekuasaan untuk bertindak dak sehingga pekerjaannya dapat dilakukan dengan baik meskipun demikian orang atau lembaga tersebut tetap harus dalam kendali, yakni mempertanggungjawabkan pekerjaannya kepada pemberi hak dan wewenang, sehingga dia tidak akan menyalahgunakan hak dan wewenangnya tersebut. (3) Pekerjaan haruslah dilakukan secara legal, yang berarti dalam melaksanakan tugastugas individu atau lembaga tentu saja harus mengikuti aturan yang telah ditetapkan, dan (4) Pekerjaan tidaklah bertentangan dengan moral aim, etika, artinya selain mengikuti aturan yang telah ditetapkan, tentu saja pekerjaan tersebut haruskah sesuai dengan moral dan etika yang berlaku umum.

\section{METODOLOGI PENELITIAN}

\section{A. Tempat dan Waktu Penelitian}

\section{Penelitian dilaksanakan Pada} PT. Cakrawala Citramega Multifinance. Jln. Ir. H. Juanda. No. 50, Ruko Ciputat Indah Permai Blok D/23. Ciputat. Tangerang. 


\section{B. Metode Penelitian}

$\begin{array}{rrr}\text { Penelitian } & \text { yang } & \text { dilakukan } \\ \text { penulis Pada } & \text { PT. } & \text { Cakrawala }\end{array}$
Citramega Multifinance, dilakukan dengan menggunakan metode Deskriptif dengan teknik survey, yang dalam hal ini pengertian deskriptif menurut Winarno Surakhmad ( 2005 : 139 ) bahwa :

'Penyelidikan deskriptif tertuju pada pemecahan masalah yang ada pada masa sekarang. Karena banyak sekali ragam penyelidikan demikian, metode penyelidikan deskriptif lebih merupakan istilah umum yang mencakup berbagai teknik deskriptif, diantaranya ialah penyelidikan yang menuturkan, menganalisa, dan mengklasifikasikan penyelidikan dengan teknik survey, interview, angket, observasi, atau teknik test'.

Berdasarkan pengertian tersebut, penelitian yang dilakukan penulis dengan cara melihat langsung kegiatan yang dilakukan pada obyek penelitian, mencatat, menganalisis, menyimpulkan, serta menggunakannya sebagai bahan penyusunan tesis ini.

Pendekatan analisis yang dipakai dalam penelitian ini adalah menggunakan pendekatan kuantitatif, jenis statistik yang dipakai dalam penelitian adalah statistik non parametrik. Menurut Sugiyono (2007:224):

"Statistik non parametrik digunakan untuk menguji hipotesis bila datanya berbentuk nominal atau ordinal, dan tidak berlandaskan asumsi bahwa distribusi data harus normal".

Peneliti menggunakan statistik nonparametrik karena data yang diolah berbentuk ordinal.

\section{Desain Penelitian}

Desain yang digunakan dalam penelitian ini bersifat deskriptif kuantitatif dengan tujuan mengetahui seberapa besar pengaruh pelatihan dan disiplin terhadap kinerja karyawan Pada PT. Cakrawala Citramega Multifinance

Tahapan penelitian dilakukan melalui beberapa tahapan, yakni menentukan fokus penelitan, lokasi penelitian, mengumpulkan data-data dan mencari sumber-sumber data sesuai dengan kebutuhan penelitian, menentukan jumlah populasi/sampel yang akan dicari sebagai responden, menguraikan variabel-variabel penelitian, menyusun instrumen, selanjutnya dilakukan pengumpulan data dan kuesioner.

Selanjutnya tahapan menganalisis data yang sudah terkumpul. Tahap terakhir merupakan kesimpulan dan saran serta rekomendasi.

\section{Defisiensi Operasional Variabel}

Secara operasional variabel perlu didefinisikan yang bertujuan untuk menjelaskan makna variabel penelitian.

\section{E. Sumber dan Cara Pengumpulan data/Informasi 1. Sumber Data}

Sumber data yang digunakan dalam penelitian ini terdiri dari dua macam yaitu data primer dan data sekunder.

1. Data Primer

Data primer adalah data yang diperoleh penulis melalui observasi atau pengamatan langsung dari 
lembaga, baik itu melalui observasi, kuesioner dan wawancara secara langsung dengan pegawai lembaga sesuai dengan kebutuhan dalam penelitian ini.

2. Data Sekunder

Data sekunder merupakan data yang diperoleh tidak langsung, yaitu data tersebut diperoleh penulis dari dokumen-dokumen lembaga dan buku-buku literatur yang memberikan informasi tentang proses Motivasi dan Kompetensi Terhadap Kinerja Karyawan di Sekretariat Jendral Dewan Perwakilan Daerah Republik Indonesia.

\section{Cara}

\section{Pengumpulan}

\section{Data/Informasi}

Proses pengumpulan data yang diperlukan dalam pembahasan ini melalui dua tahap penelitian, yaitu:

1. Studi Kepustakaan (Library Research)

Studi kepustakaan digunakan untuk mengumpulkan data sekunder dari lembaga, landasan teori dan informasi yang berkaitan dengan penelitian ini dengan cara dokumentasi. Studi dilakukan antara lain dengan mengumpulkan data yang bersumber dari literatur-literatur, bahan kuliah, dan hasil penelitian lainnya yang ada hubungannya dengan objek penelitian. Hal ini dilakukan untuk mendapatkan tambahan pengetahuan mengenai masalah yang sedang dibahas.

2. Studi Lapangan (Field Research)

Dalam penelitian ini penulis mengumpulkan data yang diperlukan dengan cara melakukan pengamatan langsung pada lembaga baik melalui observasi, penyebaran kuesioner kepada para pegawai, dan wawancara.

Penelitian Lapangan dilakukan dengan cara :
a. Wawancara adalah metode untuk mendapatkan data dengan cara melakukan tanya jawab secara langsung dengan pihak-pihak yang bersangkutan guna mendapatkan data dan keterangan yang menunjang analisis dalam penelitian.

b. Observasi adalah teknik pengumpulan data dengan cara melakukan

pengamatan langsung pada obyek yang diteliti sehingga diperoleh gambaran yang jelas mengenai masalah yang dihadapi oleh pegawai.
c. Kuesioner, adalah pengumpulan data dengan cara




$\begin{array}{lr}\text { menyebarkan } & \text { daftar } \\ \text { pertanyaan } & \text { kepada } \\ \text { responden } & \text { yang } \\ \text { dijadikan } & \text { sebagai } \\ \text { sampel penelitian. }\end{array}$

F. Teknik Penentuan Data

Pada penelitian ini, penulis menjadikan karyawan Pada PT. Cakrawala Citramega Multifinance yang populasi, yang berjumlah 35 orang.

Adapun jumlah sampel di tarik sampel jenuh yaitu keseluruhan populasi dijadikan sample

\section{G. Rancangan Analisis dan Uji Hipotesis}

\section{Rancangan Analisis}

Untuk membuktikan hipotesis yang telah dikemukakan maka dalam penelitian ini digunakan :

\section{Analisis Deskriptif Kuantitatif}

Merupakan metode yang bertujuan mengubah kumpulan data mentah menjadi bentuk yang mudah dipahami, dalam bentuk informasi yang ringkas, dimana hasil penelitian beserta analisanya diuraikan dalam suatu tulisan ilmiah yang mana dari analisis tersebut akan dibentuk suatu kesimpulan.

\section{Analisis Regresi Berganda}

Untuk mengetahui hubungan dan pengaruh antara proses rekrutmen dan seleksi dengan kinerja karyawan digunakan teknik analisis regresi berganda, untuk mengetahui besarnya pengaruh secara kuantitatif (variabel $\mathrm{X}$ ) terhadap (variabel Y). Analisis regresi menggunakan rumus persamaan regresi berganda seperti yang dikutip dalam Sugiyono (2009: 277), yaitu :

\section{Analisis Koefisien Determinasi} (R2)

$$
\text { Pada model linear berganda }
$$
ini, akan dilihat besarnya kontribusi untuk variabel bebas secara bersama-sama terhadap variabel terikatnya dengan melihat besarnya koefisien determinasi totalnya (R2). Jika (R2) yang diperoleh mendekati 1 (satu) maka dapat dikatakan semakin kuat model tersebut menerangkan hubungan variabel bebas terhadap variabel terikat. Sebaliknya jika (R2) makin mendekati 0 (nol) maka semakin lemah pengaruh variabelvariabel bebas terhadap variabel terikat.

\section{Uji Hipotesis (Uji F dan T)}

Uji ini digunakan untuk mengetahui pengaruh bersamasama variabel bebas terhadap varibel terikat. Dimana F hitung > Ftabel, maka H1 diterima atau secara bersama-sama variabel bebas dapat menerangkan variabel terikatnya secara serentak. Sebaliknya apabila Fhitung < Ftabel, maka Ho diterima atau secara bersama-sama variabel bebas tidak memiliki pengaruh terhadap variabel terikat. Untuk mengetahui signifikan atau tidak pengaruh secara bersama-sama variabel bebas terhadap variabel terikat maka digunakan probability sebesar 5\% $(\alpha=0,05)$.Jika sig $>\alpha$ $(0,05)$, maka Ho diterima H1 ditolak. Jika sig < $\alpha(0,05)$, maka Ho ditolak H1 diterima.

Sedangkan Uji $\mathrm{T}$ digunakan untuk mengetahui apakah masingmasing variabel bebasnya secara sendiri-sendiri berpengaruh secara

$$
\mathrm{Y}=\mathrm{a}+\mathrm{b} 1 \mathrm{X} 1+\mathrm{b} 2 \mathrm{X} 2
$$




\section{JENIUS}

signifikan terhadap variabel terikatnya. Dimana Ttabel > Thitung, Ho diterima.

Dan jika Ttabel < Thitung, maka H1 diterima, begitupun jika

1. Uji Validitas

Tabel 4.1

Rangkuman Hasil Perhitungan

Validitas Variabel Pelatihan (X1)

\begin{tabular}{|c|c|c|c|}
\hline $\mathbf{N}$ & $\mathbf{r}$ & $\mathbf{r}$ & Kesimpula \\
$\mathbf{o}$ & hitung & tabel & $\mathbf{n}$ \\
\hline 1 & 0.567 & 0.334 & Valid \\
\hline 2 & 0.616 & 0.334 & Valid \\
\hline 3 & 0.765 & 0.334 & Valid \\
\hline 4 & 0.744 & 0.334 & Valid \\
\hline 5 & 0.778 & 0.334 & Valid \\
\hline 6 & 0.586 & 0.334 & Valid \\
\hline
\end{tabular}

a. Uji Validitas Variabel $\operatorname{Disiplin}(\mathrm{X} 2)$

Tabel 4.2

Rangkuman Hasil Perhitungan

Validitas Variabel Disiplin (X2)

\begin{tabular}{|c|c|c|c|}
\hline $\begin{array}{c}\mathbf{N} \\
\mathbf{o}\end{array}$ & $\begin{array}{c}\mathbf{r} \\
\text { hitung }\end{array}$ & $\begin{array}{c}\mathbf{r} \\
\text { tabel }\end{array}$ & $\begin{array}{c}\text { Kesimpula } \\
\mathbf{n}\end{array}$ \\
\hline 1 & 0,422 & 0,334 & Valid \\
\hline 2 & 0,357 & 0,334 & Valid \\
\hline 3 & 0,622 & 0,334 & Valid \\
\hline 4 & 0,497 & 0,334 & Valid \\
\hline 5 & 0,625 & 0,334 & Valid \\
\hline 6 & 0,444 & 0,334 & Valid \\
\hline 7 & 0,468 & 0,334 & Valid \\
\hline 8 & 0,491 & 0,334 & Valid \\
\hline 9 & 0,412 & 0,334 & Valid \\
\hline
\end{tabular}

b. Uji Validitas Variabel Kinerja (Y) sig $>$ ó $(0,05)$, maka Ho diterima H1 ditolak dan jika sig < ́ $(0,05)$, maka Ho ditolak, H1 diterima.

\section{HASIL PENELITIAN}

Tabel 4.3

Rangkuman Hasil Perhitungan

Validitas Variabel Kinerja (Y)

\begin{tabular}{|c|c|c|c|}
\hline $\mathbf{N}$ & $\mathbf{r}$ & $\mathbf{r}$ & Kesimpula \\
$\mathbf{o}$ & hitung & tabel & $\mathbf{n}$ \\
\hline 1 & 0.518 & 0.334 & Valid \\
\hline 2 & 0.782 & 0.334 & Valid \\
\hline 3 & 0.655 & 0.334 & Valid \\
\hline 4 & 0.734 & 0.334 & Valid \\
\hline 5 & 0.595 & 0.334 & Valid \\
\hline
\end{tabular}

2. Uji Reliabilitas

Uji Reliabilitas

Variabel Pelatihan $\left(\mathrm{X}_{1}\right)$

Tabel 4.4

Uji Reliabilitas Variabel

Pelatihan $\left(\mathrm{X}_{1}\right)$

Reliability Statistics

\begin{tabular}{|r|r|}
\hline $\begin{array}{c}\text { Cronbach's } \\
\text { Alpha }\end{array}$ & N of Items \\
\hline .757 & 6 \\
\hline
\end{tabular}

*Sumber : Data Olahan Hasil SPSS 22

Berdasarkan hasil output diatas, maka r_hitung Cronbach's Alpha $(0,757)$ lebih besar jika di bandingkan dengan r_tabel yaitu berdasarkan nilai $\mathrm{N}=35$ pada taraf Signifikansi 5\% Maka di peroleh nilai sebesar (0,334).Dan dapat di simpulkan bahwar hitungCronbach's Alpha $=\overline{0,757 \quad>\text { r_tabel }}$ $=0,334$. Artinya bahwa item angket pada Variabel Pelatihan $\left(\mathrm{X}_{1}\right)$ dengan jumlah 6 butir Pernyataan yang valid dapat dinyatakan Reliabel atau 
terpercaya sebagai alat pengumpulan data dalam penelitian.Sehingga dapat di gunakan untuk penelitian tahap selanjutnya.

\section{a. Uji Reliabilitas Variabel Disiplin (X2) \\ Tabel 4.5 \\ Uji Reliabilitas Variabel \\ Disiplin (X2)}

Reliability Statistics

\begin{tabular}{|r|r|}
\hline $\begin{array}{c}\text { Cronbach's } \\
\text { Alpha }\end{array}$ & N of Items \\
\hline .569 & 9 \\
\hline
\end{tabular}

*Sumber : Data Olahan Hasil SPSS 22

Berdasarkan hasil output diatas, maka r_hitungCronbach's Alpha $(0,569)$ lebih besar jika di bandingkan dengan r_tabel yaitu berdasarkan nilai $\mathrm{N}=35$ pada taraf Signifikansi 5\% Maka di peroleh nilai sebesar $(0,334)$.Dan dapat di simpulkan bahwar_hitungCronbach's Alpha $=0,569>\mathrm{r} \_$tabel $=$ 0,334. Artinya bahwa item angket pada Variabel Disiplin(X2)dengan jumlah 9 butir Pernyataan yang valid dapat dinyatakan Reliabel atau terpercaya sebagai alat pengumpulan data dalam penelitian.Sehingga dapat di gunakan untuk penelitian tahap selanjutnya.

b. Uji Reliabilitas Variabel Kinerja (Y)

Tabel 4.6

Uji Reliabilitas Variabel Kinerja (Y)

Reliability Statistics

\begin{tabular}{|r|r|}
\hline $\begin{array}{c}\text { Cronbach's } \\
\text { Alpha }\end{array}$ & N of Items \\
\hline .663 & 5 \\
\hline
\end{tabular}

*Sumber : Data Olahan Hasil SPSS
Berdasarkan hasil output diatas, maka r_hitung Cronbach's Alpha $(0,663)$ lebih besar jika di bandingkan dengan r_tabel yaitu berdasarkan nilai $\mathrm{N}=35$ pada taraf Signifikansi 5\% Maka di peroleh nilai sebesar $(0,334)$. Dan dapat di simpulkan bahwa r_hitung Cronbach's Alpha $=0,663>r_{\text {r tabel }}$ $=0,334$. Artinya bahwa item angket pada Variabel Kinerja (Y) dengan jumlah 5 butir Pernyataan yang valid dapat dinyatakan Reliabel atau terpercaya sebagai alat pengumpulan data dalam penelitian. Sehingga dapat di gunakan untuk penelitian tahap selanjutnya.

3. Uji normalitas

Tabel 4.7

Uji Normalitas

Tests of Normality

\begin{tabular}{|l|r|r|r|r|r|r|}
\hline \multirow{2}{*}{} & \multicolumn{3}{|c|}{ Kolmogoro-Smirnov } & \multicolumn{3}{|c|}{ Shapiro-Wilk } \\
\cline { 2 - 7 } & Statistic & \multicolumn{1}{c|}{ df } & \multicolumn{1}{c|}{ Sig. } & \multicolumn{1}{c|}{ Statistic } & \multicolumn{1}{c|}{ df } & \multicolumn{1}{c|}{ Sig. } \\
\hline pelatihan & .125 & 35 & .187 & .965 & 35 & .326 \\
disipipin & .141 & 35 & .076 & .970 & 35 & .434 \\
kineria & .142 & 35 & .073 & .939 & 35 & .054 \\
\hline
\end{tabular}

a. Lilliefors Significance Correction

Sumber : Data Olahan Hasil SPSS 22

Berdasarkan table diatas di peroleh nilai Sig KS untuk Variabel Pelatihan (X1), Variabel Disiplin (X2), Variabel Kinerja (Y) secara berurutan yaitu 0,187 ; 0,076 ; dan 0,073 lebih besar daripada 0,05 atau $5 \%$.Sehingga dapat di simpulkan ketiga Variabel tersebut dinyatakan berdistribusi Normal.

4. Uji Homogenitas

Tabel 4.8 
Uji Homogenitas Variabel Pelatihan $\left(\mathrm{X}_{1}\right)$ dan Variabel Kinerja $(\mathrm{Y})$

Test of Homogeneity of Variances

kinerja

\begin{tabular}{|c|r|r|r|}
\hline $\begin{array}{l}\text { Levene } \\
\text { Statistic }\end{array}$ & df1 & \multicolumn{1}{c|}{ df2 } & \multicolumn{1}{c|}{ Sig. } \\
\hline 1.795 & 7 & 25 & .133 \\
\hline
\end{tabular}

*Sumber : Data Olahan Hasil SPSS 22

Berdasarkan table diatas di peroleh nilai Sig 0,133 lebih besar daripada 0,05 atau $5 \%$.Sehingga dapat di simpulkan Variabel X1 dan $\mathrm{Y}$ tersebut dinyatakan Homogen.

a. Uji Homogenitas Variabel Disiplin (X2) dan Variabel Kinerja (Y)

Uji Homogenitas untuk data Variabel Disiplin (X2)dan Variabel Kinerja (Y) . Dengan menggunakan bantuan spss 22 di peroleh hasil sebagai berikut :

\section{Tabel 4.9}

Uji Homogenitas Variabel Disiplin (X2) dan Variabel Kinerja (Y)

\section{Test of Homogeneity of Variances}

$$
\text { kinerja }
$$

\begin{tabular}{|r|r|r|r|}
\hline $\begin{array}{l}\text { Levene } \\
\text { Statistic }\end{array}$ & \multicolumn{1}{c|}{ df1 } & \multicolumn{1}{c|}{ df2 } & \multicolumn{1}{c|}{ Sig. } \\
\hline 2.357 & 7 & 24 & .055 \\
\hline
\end{tabular}

*Sumber : Data Olahan Hasil SPSS 22

Berdasarkan table diatas di peroleh nilai Sig 0,055 lebih besar daripada 0,05 atau 5\% .Sehingga dapat di simpulkan Variabel X1 dan $\mathrm{Y}$ tersebut dinyatakan Homogen. b. Uji Homogenitas Variabel Pelatihan (X1) dan Variabel disiplin (X2)

Tabel 4.10

Test of Homogeneity of Variances

pelatihan
\begin{tabular}{|r|r|r|c|}
\hline $\begin{array}{c}\text { Levene } \\
\text { Statistic }\end{array}$ & \multicolumn{1}{c|}{$\mathrm{df1}$} & $\mathrm{d}+2$ & $\mathrm{Sig}$. \\
\hline 2.132 & 7 & 24 & .079 \\
\hline
\end{tabular}

*Sumber : Data Olahan Hasil SPSS 22

Berdasarkan tabel diatas di peroleh nilai Sig 0,079lebih besar daripada 0,05 atau 5\% .Sehingga dapat di simpulkan Variabel X1 dan X2 tersebut dinyatakan Homogen.

5. Uji Korelasi Antara Pelatihan dan Disiplin dengan Kinerja a. Korelasi Variabel Pelatihan $\left(\mathrm{X}_{1}\right)$ dan Variabel Kinerja (Y)

Tabel 4.11

Korelasi Variabel Pelatihan $\left(\mathrm{X}_{1}\right)$ dan Variabel Kinerja (Y)

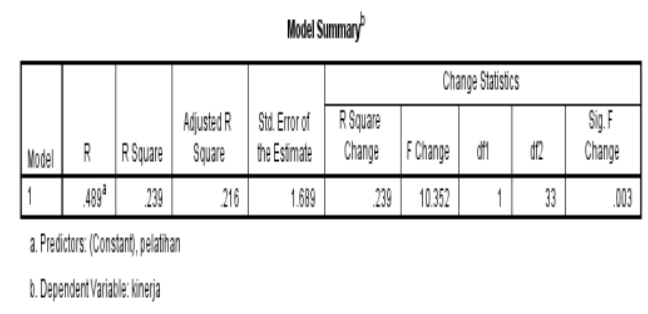

*Sumber : Data Olahan Hasil SPSS 22

Berdasarkan table diatas di peroleh nilai korelasi (R) antara X1 dan $\mathrm{Y}$ yaitu 0,489 terjadi hubungan yang positif karena nilai $r>0$ yaitu sebesar 0,489. Artinya hubungan antara X1 dan Y terkategori Sedang karena berada pada interval $0,40-$ 0,599 .

b. Korelasi Variabel Disiplin (X2) dan Variabel Kinerja (Y) 
Tabel 4.12

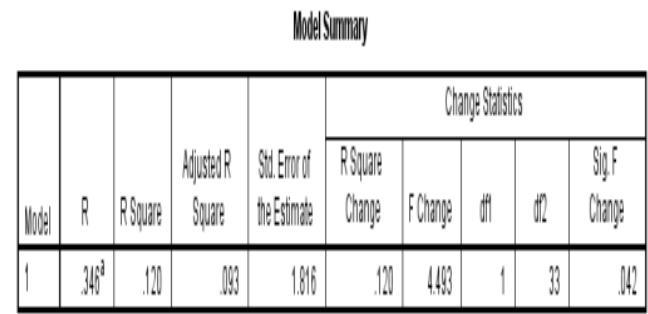

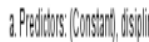

*Sumber : Data Olahan Hasil SPSS 22

Berdasarkan table diatas di peroleh nilai korelasi $(\mathrm{R})$ antara $\mathrm{X} 2$ dan $\mathrm{Y}$ yaitu 0,346 terjadi hubungan yang positif karena nilai $r>0$ yaitu sebesar 0,346. Artinya Hubungan antara X2 dan Y terkategori rendah karena berada pada interval $0,20-$ 0,399

c. Korelasi Variabel Pelatihan $\left(\mathrm{X}_{1}\right)$ dan Variabel Disiplin (X2)

Tabel 4.13

\begin{tabular}{|c|c|c|c|c|c|c|c|c|c|}
\hline \multirow[b]{3}{*}{ Notol } & \multicolumn{9}{|c|}{ Model Summay } \\
\hline & \multirow[b]{2}{*}{$R$} & \multirow[b]{2}{*}{ RSpuare } & \multirow[b]{2}{*}{$\begin{array}{l}\text { AjustardR } \\
\text { Syaler }\end{array}$} & \multirow[b]{2}{*}{$\begin{array}{l}\text { Sot Erono of } \\
\text { the Esinder }\end{array}$} & \multicolumn{5}{|c|}{ Changes Satisicics } \\
\hline & & & & & $\begin{array}{l}\text { RSgugate } \\
\text { Chargye }\end{array}$ & F Changes & oth & th & $\begin{array}{l}\text { Sigf } \\
\text { Changes }\end{array}$ \\
\hline 1 & $.55^{\circ}$ & 209 & .185 & 2753 & .209 & 8729 & 1 & 33 & .006 \\
\hline
\end{tabular}

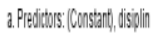

*Sumber : Data Olahan Hasil SPSS 22

Berdasarkan table diatas di peroleh nilai korelasi (R) antara X1 dan X2 yaitu 0,457 terjadi hubungan yang positif karena nilai $\mathrm{r}>0$ yaitu sebesar 0,457. Artinya hubungan antara X1 dan X2 terkategori sedang karena berada pada interval $0,40-$ 0,599

d. Korelasi Variabel Pelatihan $\left(\mathrm{X}_{1}\right)$ dan Variabel Disiplin (X2) terhadap Variabel Kinerja (Y) .

Tabel 4.14

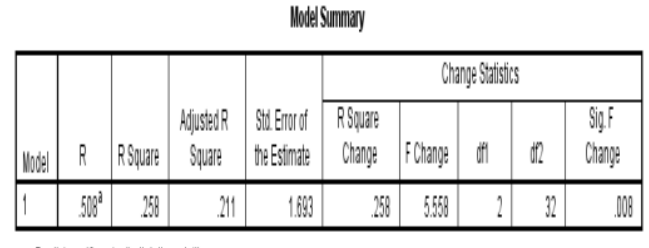

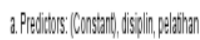

*Sumber : Data Olahan Hasil SPSS 22

Berdasarkan table diatas di peroleh nilai korelasi $(\mathrm{R})$ antara $\mathrm{X} 1$ dan $\mathrm{X} 2$ terhadap $\mathrm{Y}$ yaitu 0,508 , terjadi hubungan yang positif karena nilai $r$ $>0$ yaitu sebesar 0,508. yang atinya Hubungan antara X1 dan X2 terhadap $\mathrm{Y}$ terkategori sedang karena berada pada interval $0,40-0,599$.

6. Analisis Regresi Berganda

Tabel 4.15

Analisis Regresi Berganda

Coefficients $^{a}$

\begin{tabular}{|c|c|c|c|c|c|c|}
\hline \multirow[b]{2}{*}{ Mode } & & \multicolumn{2}{|c|}{ Unstandardized Coefficients } & \multirow{2}{*}{$\begin{array}{c}\text { Standardized } \\
\text { Coefficients } \\
\text { Beta }\end{array}$} & \multirow[b]{2}{*}{$t$} & \multirow[b]{2}{*}{ Sig. } \\
\hline & & $\mathrm{B}$ & Std. Error & & & \\
\hline \multirow[t]{3}{*}{1} & (Constant) & 11.114 & 3.685 & & 3.016 & .005 \\
\hline & pelatihan & .261 & .107 & .418 & 2.439 & .020 \\
\hline & disiplin & .097 & .107 & .155 & .906 & .372 \\
\hline
\end{tabular}

*Sumber : Data Olahan Hasil SPSS 22

Berdasarkan data di atas maka di peroleh : $\alpha=11.114, \beta_{1}=0.261 \mathrm{dan}$ $\beta_{2}=0.097$ sehingga persamaan regresi gandanya dapat di tentukan sebagai berikut :

$$
\begin{gathered}
\hat{Y}=\alpha+\beta_{1} X_{1}+\beta_{2} X_{2} \\
\hat{Y}=11.114+0.261 X_{1}+0.097 X_{2}
\end{gathered}
$$

Misalkan Variabel X1 ( Pelatihan $)=$ 20 dan Disiplin $(X 2)=40$ Maka Dapat di prediksikan Nilai Kinerja (Y) yaitu :

$$
\begin{gathered}
\hat{Y}=11.114+0.261 X_{1}+0.097 X_{2} \\
\hat{Y}=11.114+0.261(20) \\
+0.097(40) \\
\hat{Y}=20.214
\end{gathered}
$$


Langkah-langkah dalam analisis linear berganda adalah:

a. Uji Parsial (uji t)

1) Uji Parsial X1 terhadap $Y$

Sesuai dengan perhitungan korelasi diatas antar $\mathrm{X} 1$ terhadap $\mathrm{Y}$ yaitu 0,489 yang terkategori Sedang. Tahap berikutnya adalah untuk uji Parsial dengan mensubstitusikan nilai $r$ ke persamaan $t$ yaitu :

$$
\begin{aligned}
\mathbf{t}=\frac{r \sqrt{\boldsymbol{n}-\mathbf{2}}}{\sqrt{\mathbf{1 - ( r ) ^ { 2 }}}} & \\
\mathbf{t} & =\frac{0,489 \sqrt{\mathbf{3 5 - 2}}}{\sqrt{\mathbf{1 - ( 0 , 4 8 9 ) ^ { 2 }}}}=
\end{aligned}
$$

\section{22039}

$\mathrm{dk}($ Drajat Kebebasan $)=\mathrm{N}-2-1=35-$ $2-1=32$ dan taraf signifikan sebesar $5 \%$ dengan metode 2 arah sehingga di peroleh $t$ hitung $=3$,22039. Lebih besar daripada t table yaitu 2,037 artinya variabel Pelatihan secara persial berpengaruh secara signifikan terhadap Variabel kinerja karyawan.Maka dalam hipotesis $\mathrm{Ha}$ 1 di terima dan Ho 1 di tolak yaitu terdapat pengaruh Pelatihan terhadap Kinerja Pada PT. Cakrawala Citramega Multifinance.

2) Uji Parsial X2 terhadap Y

Sesuai dengan perhitungan korelasi diatas antar X2 terhadap $\mathrm{Y}$ yaitu 0,346 yang terkategori Sedang. Tahap berikutnya adalah untuk uji Parsial dengan mensubstitusikan nilai $r$ ke persamaan $t$ yaitu :

\section{27864}

$$
t=\frac{r \sqrt{n-2}}{\sqrt{1-(r)^{2}}}
$$

$$
\mathbf{t}=\frac{0,346 \sqrt{\mathbf{3 5 - 2}}}{\sqrt{\mathbf{1 - ( 0 , 3 4 6 ) ^ { 2 }}}}=
$$

$\mathrm{dk}($ Drajat Kebebasan $)=\mathrm{N}-2-1=35-$ $2-1=32$ dan taraf signifikan sebesar $5 \%$ dengan metode 2 arah sehingga di peroleh $\mathrm{t}$ hitung $=2.27864 \mathrm{Lebih}$ besar daripada $t$ tabel yaitu $=2,037$ artinya variabel disiplin secara persial berpengaruh secara signifikan terhadap kinerja karyawan.Maka dalam hipotesis Ha 2 di terima dan Ho 2 di tolak yaitu terdapat pengaruh Disiplin terhadap Kinerja Pada PT. Cakrawala Citramega Multifinance.

b. Uji simultan (Uji F)

Sesuai dengan perhitungan korelasi X1 danX2secara bersama sama terhadap $\mathrm{Y}$ yaitu 0,508yang terkategori Sedang. Tahap berikutnya adalah untuk uji Simultan dengan mensubstitusikan nilai $\mathrm{r}$ ke persamaan Fyaitu :

$\mathbf{F h}=\frac{R^{2}(N-K-1)}{\left(1-R^{2}\right) K}$

$\mathbf{F h}=\frac{\mathbf{0 , 5 0 8 ^ { 2 } ( 3 5 - 2 - 1 )}}{\left(1-0,508^{2}\right) \mathbf{2}}=\mathbf{5 , 5 6 5 2}$

$\mathrm{dk}$ (Drajat Kebebasan) pembilang = $\mathrm{K}=2$, $\mathrm{dk}$ (Drajat Kebebasan) penyebut $=\mathrm{N}-2-1=35-2-1=32$ dan taraf signifikan sebesar 5\% sehingga di peroleh $\mathrm{F}$ hitung $=5$,5652 Lebih besar daripada $\mathrm{F}$ table $=3,30$ artinya variabel Pelatihan dan disiplin secara Simultan berpengaruh sangat signifikan terhadap kinerja karyawan.Maka dalam Hipotesis $\mathrm{Ha}$ 4 di terima dan Ho 4 di tolak yaitu terdapat pengaruh Pelatihan dan Disiplin terhadap Kinerja Pada PT. Cakrawala Citramega Multifinance.

c. Uji Koefisien Determinasi

Untuk mengetahui seberapa besar presentasi pengaruh pelatihan dan Disiplin terhadap kinerja karyawanPada PT. Cakrawala Citramega Multifinance dirumuskan sebagai berikut:

$$
\begin{aligned}
\mathrm{KD} & =\mathrm{r}^{2} \times \mathbf{1 0 0 \%} \\
\mathrm{KD} & =\mathbf{0}, \mathbf{5 0 8}^{2} \times 100 \% \\
\mathrm{KD}=\mathbf{2 5 , 8 0} \% &
\end{aligned}
$$

Berdasarkan perhitngan di atas maka dapat di simpulkan bahwa kontribusi Pengaruh Variabel X (bebas) yaitu Variabel pelatihan (X1) dan Variabel disiplin (X2) terhadap Variabel 
KInerja(Y/terikat) yaitu sebesar $\mathbf{2 5 , 8 0} \%$ dan sisasnya $74,20 \%$ factor lain yang belum di teliti yang mempengaruhi Variabel Kinerja (Y/terikat).

\section{A. Pembahasan}

1. Pengaruh pelatihan terhadap kinerja karyawan Pada PT. Cakrawala Citramega Multifinance. Berdasarkan hasil data yang telah peneliti kumpul kan dari pernyataan yang di sebarkan kepada karyawanPada PT. Cakrawala Citramega Multifinance sebanyak 35 responden. Setelah di lakukan uji Validitas, Reliabilitas, Normalitas dan Homogenitas terhadap Pernyataan yang di sebarkan, maka peneliti kemudian melakukan perhitungan terhadap data yang telah di kumpulkan dengan bantuan SPSS dan mendapati hasil sebagai berikut: a. Berdasarkan perhitungan uji korelasi (R) antara Pelatihan $\left(\mathrm{X}_{1}\right)$ danKinerja $(\mathrm{Y})$ yaitu 0,489 terjadi hubungan yang positif karena nilai $\mathrm{r}>0$ yaitu sebesar 0,489. Artinya hubungan antara Pelatihan $\left(\mathrm{X}_{1}\right)$ danKinerja $(\mathrm{Y})$ terkategori Sedang karena berada pada interval $0,40-0,599$.

b. Berdasarkan perhitungan secara Parsial (uji t) maka di dapati hasil penelitian dsebagai berikut : $\mathrm{dk}$

(Drajat

Kebebasan $)=\mathrm{N}-2-1=35-2-1=32$ dan taraf signifikan sebesar $5 \%$ dengan metode 2 arah sehingga di peroleh $\mathrm{t}$ hitung $=3,22039$ lebih besar dari pada $t$ table yaitu 2,037artinya variabel Pelatihan secara persial berpengaruh secara signifikan terhadap Variabel kinerja karyawan.
Dari hasil tersebut maka di dapati bahwa terdapat Pengaruh yang signifkan antara pelatihan terhadap kinerja karyawan Pada PT. Cakrawala Citramega Multifinance dengan kategori Sedang.Ini juga sekaligus membuktikan bahwa dalam hipotesis H1 di terima yaitu terdapat pengaruh Pelatihan terhadap Kinerja Pada PT. Cakrawala Citramega Multifinance.

2. Pengaruh kedisiplinan terhadap kinerja karyawan Pada PT. Cakrawala Citramega Multifinance. Berdasarkan hasil data yang telah peneliti kumpul kan dari pernyataan yang di sebarkan kepada karyawanPada PT. Cakrawala Citramega Multifinance sebanyak 35 responden. Setelah di lakukan uji Validitas, Reliabilitas, Normalitas dan Homogenitas terhadap Pernyataan yang di sebarkan, maka peneliti kemudian melakukan perhitungan terhadap data yang telah di kumpulkan dengan bantuan SPSS dan mendapati hasil sebagai berikut

a. Berdasarkan perhitungan uji korelasi (R) antara Disiplin (X2) dan Kinerja (Y) yaitu 0,346 terjadi hubungan yang positif karena nilai $\mathrm{r}$ $>0$ yaitu sebesar 0,346. Artinya Hubungan antara X2 dan Y terkategori rendah karena berada pada interval 0,20-0,399.

b. Berdasarkan perhitungan Uji Parsial (uji t) maka di dapati hasil penelitian dsebagai berikut :

$\mathrm{dk}($ Drajat Kebebasan $)=\mathrm{N}-2-1=35-$ $2-1=32$ dan taraf signifikan sebesar $5 \%$ dengan metode 2 arah sehingga di peroleh t hitung $=2.27864$ Lebih besar dari pada $\mathrm{t}$ tabel yaitu = 2,037artinya variabel disiplin secara 
persial berpengaruh secara signifikan terhadap kinerja karyawan.

Dari hasil tersebut maka di dapati bahwa terdapat Pengaruh yang signifkan antara disiplinterhadap kinerja karyawan Pada PT. Cakrawala Citramega Multifinance namun untuk variable ini pengaruhnya terkategoriRendah.Ini juga sekaligus membuktikjan bahwa hipotesis $\mathrm{H} 2$ di terima yaitu terdapat pengaruh kedisiplinan terhadap Kinerja Pada PT. Cakrawala Citramega Multifinance.

3. Pengaruh pelatihan dan disiplin terhadap kinerja karyawan Pada PT. Cakrawala Citramega Multifinance

Berdasarkan hasil data yang telah peneliti kumpul kan dari pernyataan yang di sebarkan kepada karyawanPada PT. Cakrawala Citramega Multifinance sebanyak 35 responden. Setelah di lakukan uji Validitas, Reliabilitas, Normalitas dan Homogenitas terhadap Pernyataan yang di sebarkan, maka peneliti kemudian melakukan perhitungan terhadap data yang telah di kumpulkan dengan bantuan SPSS dan mendapati hasil sebagai berikut

a. Berdasarkan perhitungan uji korelasi (R) antara X1 dan X2 terhadap $Y$ yaitu 0,508 , terjadi hubungan yang positif karena nilai $r$ $>0$ yaitu sebesar 0,508. yang atinya Hubungan antara X1 dan X2 terhadap $\mathrm{Y}$ terkategori sedang karena berada pada interval $0,40-0,599$.

b. Berdasarkan perhitungan Uji Simultan (uji F) maka di dapati hasil penelitian sebagai berikut :

$\mathrm{dk}$ (Drajat Kebebasan) pembilang $=$ $\mathrm{K}=2$, dk (Drajat Kebebasan) penyebut $=\mathrm{N}-2-1=35-2-1=32$ dan taraf signifikan sebesar 5\% sehingga di peroleh $\mathrm{F}$ hitung $=5,5652$ Lebih besar dari pada $\mathrm{F}$ table $=3,30$ artinya variabel Pelatihan dan disiplin secara Simultan berpengaruh sangat signifikan terhadap kinerja karyawan.

c. Berdasarkan perhitngan koefisien determinasi maka dapat di simpulkan bahwa kontribusi Pengaruh Variabel X (bebas) terhadap Variabel Y (terikat) yaitu sebesar $25,80 \%$.

Dari hasil tersebut maka di dapati bahwa terdapat Pengaruh yang sangat signifkan antara disiplin terhadap kinerja karyawan Pada PT. Cakrawala Citramega Multifinance dengan kategori Sedang. Selain itu Berdasarkan perhitngan koefisien determinasi di dapati bahwa kontribusi pengaruh Variabel $X$ (bebas) terhadap Variabel Y (terikat) yaitu sebesar 25,80 \%.Dan ini juga sekaligus membuktikan bahwa hipotesis $\mathrm{H} 3$ di terima yaitu terdapat pengaruh Pelatihan dan kedisiplinan terhadap Kinerja Pada PT. Cakrawala Citramega Multifinance.

\section{KESIMPULAN DAN SARAN}

\section{A. Kesimpulan}

Berdasarkan hasil penelitian dan pembahasan yang di lakukan kepada karyawan PT. Cakrawala Citramega Multifinance maka peneliti menarik kesimpulan sebagai berikut:

1. Terdapat pengaruh yang sangat signifikan antara pelatihan terhadap kinerja karyawan Pada PT. Cakrawala Citramega Multifinance. Pengaruh ini di 
buktikan melalui uji koefisien korelasi dan di dapati hasil sebesar 0,489 dan uji Parsial (Uji t) sebesar 3,22039. Maka di temukan hasil pengaruhnya dengan terkategori Sedang.

2. Terdapat pengaruh yang signifikan antara disiplin terhadap kinerja karyawan Pada PT. Cakrawala Citramega Multifinance. Pengaruh ini di buktikan melalui uji koefisien korelasi dan di dapati hasil sebesar 0,346 dan uji Parsial (Uji t)sebesar 2.27864. Maka di temukan hasil pengaruhnya dengan terkategori Rendah.

3. Terdapat pengaruh yang sangat signifikan antara pelatihan dan disiplin terhadap kinerja karyawan Pada PT. Cakrawala Citramega Multifinance Pengaruh ini di buktikan melalui uji koefisien korelasi dan di dapati hasil sebesar 0,508 dan Uji Simultan (uji F) sebesar 5,5652. Persentasi $25,80 \%$.

B. Saran

Melihat dari kesimpulan yang ada maka peneliti memiliki beberapa saran yang mungkin bisa bermanfaat bagi perusahaan PT. Cakrawala Citramega Multifinance:

1. Perusahaaan sebaiknya memiliki sistem pelatihan yang baik agar seluruh karyawan dapat mengikutinya dengan mudah dan mendapatkan hasil yang signifikan dari pelatihan tersebut. Materi yang mudah dipahami, Metode yang sederhana dan Instruktur yang cakap dapat menentukan hasil dari pelatihan yang di ikuti karyawan.

2. Perlu adanya peraturan yang tegasdari perusahaan bagi para karyawan terkait kedisiplinan dalam bekerja, agar memberikan efek jera bagi para pelanggar kedisiplinan. Dan peraturan yang menyeluruh serta tidak tebang pilih.

3. Jika semuanya telah berjalan sesuai dengan sistem yang di jalankan maka evaluasi terkait kinerja para karyawan patut untuk di perhatikan. Agar dapat memberikan refrensi terkait apa yang harus di perbaiki dalam perusahaan, apa yang harus di pertahankan dan apa yang harus di tambahkan untuk mencapai tujuan yang di inginkan.

\section{DAFTAR PUSTAKA}

A.A. Anwar Prabu Mangkunegara (2005), Manajamen Sumber Daya Manusia Perusahaan, PT Remaja Rosdakarya, Bandung.

As'ad, Moh (2005). Psikologi Indrustri. (Edisi IV). Yogyakarta. Liberty.

Gomes (2005). Organisasi dan Manajemen- PerilakuStruktur-Proses, terjemahan Djoerban Wahid, Penerbit Erlangga, Jakarta. 
Hasibuan, Malayu SP (2005), Manajemen dasar, Pengertian dan Masalah, C.V. Haji Masanggung, Jakarta.

Hasibuan, Malayu SP (2007), Manajemen Sumber Daya Manusia, Edisi Revisi, Penerbit Bumi Aksara, Jakarta.

Henry Simamora (2005), Manajemen Sumber Daya Manusia, STIE YKPN Bandung.

Sadili Samsudin (2005), Manajemen Sumber Daya Manusia, Pustaka Setia, Bandung.

Slameto (2010), Belajar Dan Faktor-Faktor Yang Mempengaruhinya, Rineka Cipta, Jakarta

Soeratmo dan Arsyad Lincolin (2005), Metodologi Penelitian Untuk Ekonomi dan Bisnis, Edisi Revisi, UPP AMP YKPN, Universitas Gajah Mada, Yogyakarta.

Sugiyono (2007), Metode Penelitian Bisnis, Alfabeta, Bandung.

Suharsimi Arikunto (2005), Manajemen Penelitian, Edisi Revisi, Cetakan Ketujuh, Rineka Cipta, Jakarta.

(2006), Prosedur Penelitian, Edisi Revisi VI, Cetakan
Ketigabelas, Rineka Cipta, Jakarta.

Surakhmad Winarno (2005), Pengantar Penelitian Ilmiah, Tarsito, Bandung.

Susilo Martoyo (2005), Manajemen Sumber Daya Manusia, Edisi Kedua, BPFE, Yogyakarta.

Taufik (2010), Strategi Belajar Mengajar,Inti Prima, Jakarta

Terry, George R, (2005). Personal Management, Edisi Ketujuh, Richard D Irwin, Inc., Homewood, Illinois.

Triton Prawira Budi (2006), SPSS 13.0 Terapan, Riset Statistik Parametrik, ANDI, Yogyakarta.

Winardi, (2005). Manajemen Supevisi, Penerbit Mandar Maju, Bandung. 